\title{
Checklist of the Bromeliaceae from Pedra dos Pontões, Mimoso do Sul, Espírito Santo, Brazil, with four first records for the state
}

\author{
Dayvid Rodrigues Couto ${ }^{1,5}$, Vitor da Cunha Manhães ${ }^{2}$, \\ Fernanda Campanharo Favoreto ${ }^{3}$ \& Ana Paula Gelli de Faria ${ }^{4}$ \\ 'Programa de Pós-graduação em Ciências Florestais, Universidade Federal do Espírito Santo - UFES, \\ Av. Governador Lindemberg, 316, Centro, CEP 29550-000, Jerônimo Monteiro, ES, Brasil. \\ http://www.florestaemadeira.ufes.br/ \\ ${ }^{2}$ Prefeitura Municipal de Alegre, Secretaria Municipal de Saúde, Vigilância Ambiental; \\ Rua Major Quintino, s/n, Centro, CEP 29500-000, Alegre, ES, Brasil \\ ${ }^{3}$ Programa de Pós-graduação em Ecologia, Universidade Federal de Juiz de Fora - UFJF, \\ Campus Universitário, s/n, São Pedro, CEP 36036-900, Juiz de Fora, MG, Brasil. \\ http://www.ufjf.br/ecologial \\ ${ }^{4}$ Instituto de Ciências Biológicas, Departamento de Botânica, Universidade Federal de Juiz de \\ Fora-UFJF, Campus Universitário, s/n, São Pedro, CEP 36036-900, Juiz de Fora, MG, Brasil. \\ http://www.ufjf.br/icb/ \\ ${ }^{5}$ Corresponding author: Dayvid Rodrigues Couto, e-mail: dayvidcouto@hotmail.com
}

COUTO, D.R., MANHÃES, V.C., FAVORETO, F.C. \& FARIA, A.P.G. Checklist of the Bromeliaceae from Pedra dos Pontões, Mimoso do Sul, Espírito Santo, Brazil, with four first records for the state. Biota Neotrop. 13(4): http://www.biotaneotropica.org.br/v13n4/en/abstract?article+bn01813042013

\begin{abstract}
Bromeliaceae is one of the most relevant taxonomic groups of the Atlantic Forest, where the Brazilian southeastern region stands out as a center of diversity and endemism for many taxa of the family. We present a checklist of the 12 genera and 44 species of Bromeliaceae from the Pedra dos Pontões, in Mimoso do Sul municipality, Espírito Santo state, southeastern Brazil. The Bromelioideae (22 species) was the subfamily with most taxonomic diversity, followed by Tillandsioideae (18 species) and Pitcairnioideae (four species). We also report the first occurrence of four species (A. squarrosa, N. antoineanum, V. pseudoatra and V. pardalina ) for the Espírito Santo state. Almost half of the taxa surveyed inhabit exclusively the vegetation associated to the rocky outcrops, what points out the importance of this kind of environment in the maintenance of the diversity for many species of bromeliads. We also highlight that the documentation and study of the flora of Espírito Santo, which is considered a gap in the knowledge of the plant diversity along the entire Brazilian Atlantic Forest, assumes a relevant aspect in view of the high levels of degradation of the natural ecosystems observed in the state.
\end{abstract}

Keywords: Atlantic Forest, bromeliads, conservation, rocky outcrops, taxonomy.

COUTO, D.R., MANHÃES, V.C., FAVORETO, F.C. \& FARIA, A.P.G. Checklist das Bromeliaceae da Pedra dos Pontões, Mimoso do Sul, Espírito Santo, Brasil, com notas sobre o primeiro registro de quatro espécies para o Estado. Biota Neotrop. 13(4): http://www.biotaneotropica.org.br/v13n4/pt/abstract?article+bn01813042013

Resumo: Bromeliaceae é um dos grupos taxonômicos mais relevantes da Floresta Atlântica, onde o sudeste do Brasil se destaca como um centro de diversidade e endemismo de muitos táxons da família. Nós apresentamos uma lista de 12 gêneros e 44 espécies de Bromeliaceae da Pedra dos Pontões, no município de Mimoso do Sul, estado do Espírito Santo, sudeste do Brasil. Bromelioideae (22 espécies) foi a subfamília com maior diversidade taxonômica, seguida por Tillandsioideae (18 espécies) e Pitcairnioideae (quatro espécies). Nós também reportamos a primeira ocorrência de quatro espécies (A. squarrosa, $N$. antoineanum, $V$. pseudoatra e $V$. pardalina ) para o estado do Espírito Santo. Quase a metade dos táxons levantados habita exclusivamente a vegetação associada ao afloramento rochoso, o que ressalta a importância deste tipo de ambiente na manutenção da diversidade de muitas espécies de bromélias. Destacamos também que a documentação e estudo da flora do Espírito Santo, considerada uma lacuna no conhecimento da diversidade de plantas ao longo da Floresta Atlântica, assume um aspecto relevante tendo em vista os altos níveis de degradação dos ecossistemas naturais observados no estado. Palavras-chave: Floresta Atlântica, bromélias, conservação, afloramentos rochosos, taxonomia. 


\section{Introduction}

The Brazil's Atlantic Forest is considered a world biodiversity hotspot (Myers et al. 2000), where studies and actions for conservation are essential to reverse the present status of its degradation. The climatic and geomorphologic heterogeneity is a remarkable character of this domain, and its great biodiversity can be explained by the multiplicity of habitats, such as humid, deciduous and semi deciduous forests, campos de altitude, campos rupestres, as well as sandy coastal plains (restingas) and mangroves (Rizzini 1997).

Bromeliaceae is one of the most relevant taxonomic groups of the Atlantic domain, and nearly $26 \%$ of the Brazilian bromeliad species occurs in this domain (Martinelli et al. 2008). The Brazilian southeastern figures as a center of diversity and endemism for many bromeliad taxa and in this context, the state of Espírito Santo stands out presenting Bromeliaceae as the third largest angiosperm family in species richness (Fraga et al. 2007). This diversity can be even greater, taking into account that the Espírito Santo still represents a gap in the knowledge of the plant diversity along the Atlantic Forest. This is particullarly observed in the south portion of the state, where a remarkable number of new bromeliad species was discovered in the past years: Pitcairnia azouryi (Martinelli \& Forzza 2006); Alcantarea patriae (Versieux \& Wanderley 2007), Nidularium alegrense, Pitcairnia capixaba, Tillandsia castelensis (Leme et al. 2010a), Pitcairnia diversifolia (Leme et al. 2010b), Pitcairnia abyssicola Leme \& L. Kollmannn and Neoregelia dayvidiana Leme \& A. P. Fontana (Leme et al. 2009), most of them inhabiting the vegetation associated to rocky outcrops. The scarcity of biological information for many mountain regions in Brazil, particularly those within the
Atlantic Forest domain was observed by Martinelli (2007). Due to the high diversity, endemism and specialization of the flora, Esgario et al. (2009) also emphasized the urgent need for a larger number of studies on rocky environments found in Espírito Santo.

The high bromeliad diversity pointed for the Espírito Santo, however, contrasts with the conservation status of many species. Bromeliaceae contributes with $13.5 \%$ of the total number of the endangered species registered for the flora of the state (Simonelli et al. 2007), where the disappearance of natural habitats due to the forest fragmentation and the exploratory pressures for ornamental purposes are among the main causes of decline in bromeliad populations. Besides, mining activities for exploration of ornamental rocks have reached the typical vegetation of the rocky outcrops, once immune to the agricultural expansion (Assis et al. 2007).

The goals of this paper were to present an inventory of the Bromeliaceae from the rocky outcrop Pedra dos Pontões, situated in the south portion of Espírito Santo state, east of Brazil, with reports of the first record of four species for the state. We also present ecological information about preferential habitats, estimation of local abundance and conservation status for the studied taxa.

\section{Material and Methods}

\section{Study site}

The studied area is situated at the municipality of Mimoso do Sul, south of Espírito Santo state, between the coordinates $20^{\circ} 56^{\prime}$ $43^{\prime \prime}-20^{\circ} 56^{\prime} 27^{\prime \prime} \mathrm{S}$ and $41^{\circ} 32^{\prime} 21^{\prime \prime}-41^{\circ} 34^{\prime} 5^{\prime \prime} \mathrm{W}$ (Figure 1). According to Köppen (1948), the climate type is Cwb, characterized by humid
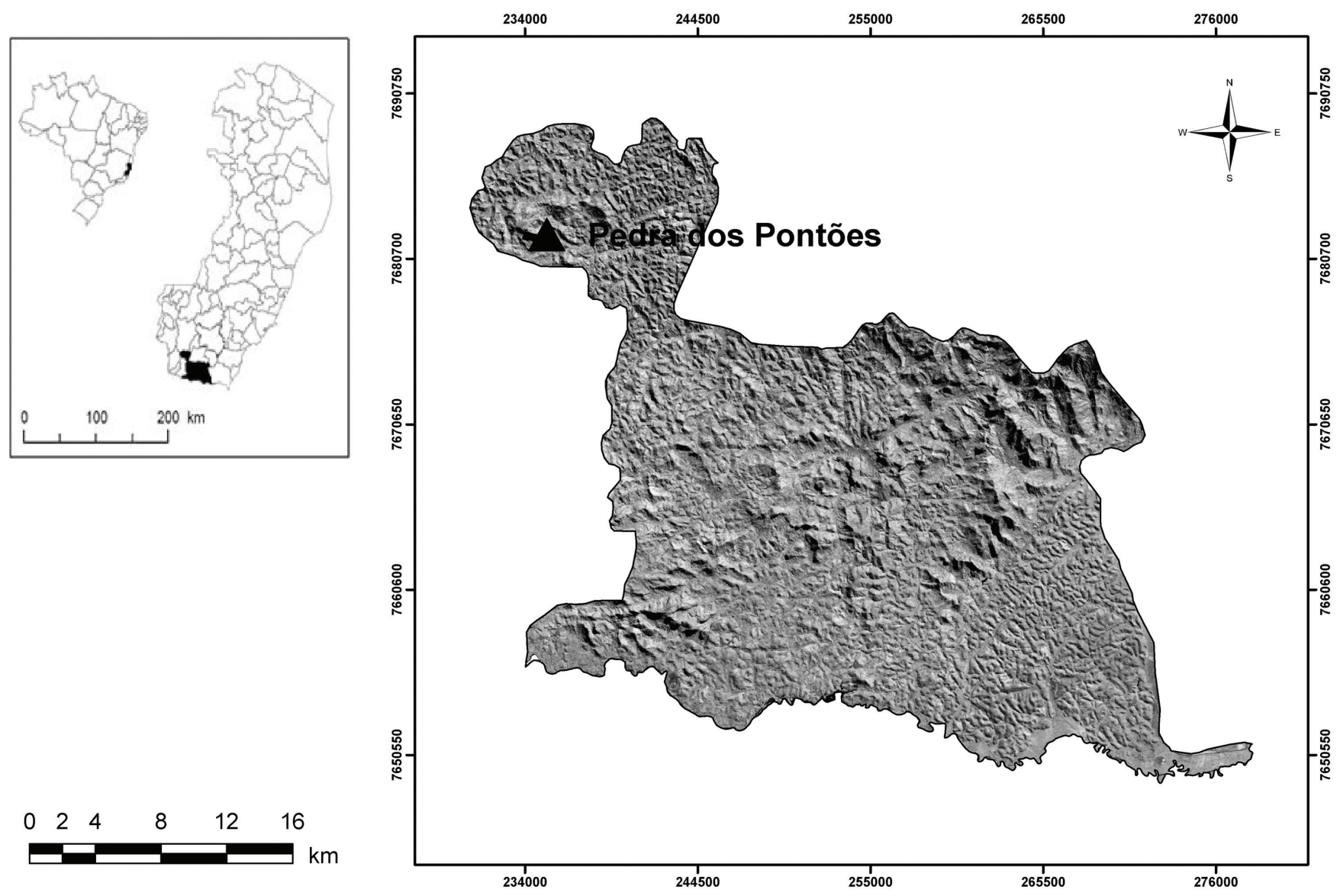

Figure 1. Location of the Pedra dos Pontões, municipality of Mimoso do Sul, Espírito Santo state, Brazil. 
summers and cold and dry winters. With approximately 350 ha, the area presents an altitudinal gradient ranging from 700 to $1.400 \mathrm{~m}$, including the Pedra dos Pontões, which is considered the highest outcrop of the region. It consists of a granitic-gneissic complex (Companhia... 1995) with patches of rocky vegetation, inserted in a transition area between montane semi-deciduous forest and montane dense ombrophilus forest (Veloso et al. 1991), besides a disturbed matrix composed by coffee plantations (Coffea arabica L.), pasture and eucalyptus' silviculture (Figure 2).

\section{Data collection}

Field expeditions were conducted between the years 2004 and 2012 in areas of montane dense ombrophilus forest and rocky vegetation. Fertile specimens were collected, photographed and deposited in the herbarium MBML, with duplicates sent to the herbarium VIES. Notes on substrate preference (habit epiphytic, rupicolous or terrestrial), type of vegetation, as well as the geographic coordinates and altitudinal reference using GPS were taken in the field. The apparent local abundance was categorized in four classes, based on simple visual estimation (according to Versieux et al. (2010), with modifications): 1) common: large populations widespread in the two types of vegetation studied; 2) occasional: small populations occurring in the two types of vegetation studied; 3 ) restrict: large population, limited to a particular type of vegetation. 4) rare: small population observed in a particular type of habitat.

The nomenclature of the species and information about geographical distribution and endemism are cited according to Forzza et al. (2010) and Govaerts et al. (2012). The official lists of endangered species consulted were: a) Official List of Endangered Species of Brazilian Flora (Brasil 2008) and b) List of Endangered Species of Espírito Santo state (Espírito Santo 2005).

\section{Results}

We registered 12 genera and 44 species for the Pedra dos Pontões, comprising the three subfamilies traditionally recognized for Bromeliaceae (Table 1). The richest genus was Vriesea (10 species), followed by Billbergia (seven species), Aechmea and Tillandsia, with six species each one. The epiphytic habit occurs in $60.4 \%$ of the surveyed species (including four taxa registered as facultative epiphytes). The terricolous and rupicolous habits totalize $20.8 \%$ and $18.7 \%$, respectively (Figure 3 ).

Twenty one species inhabit exclusively the rocky outcrops vegetation (nearly $48 \%$ of the total taxa surveyed), end the genera Alcantarea, Bromelia, Catopsis, Pitcairnia and Quesnelia have restricted occurrence to this environment. The remaining taxa (10 species) were registered exclusively for montane forest and
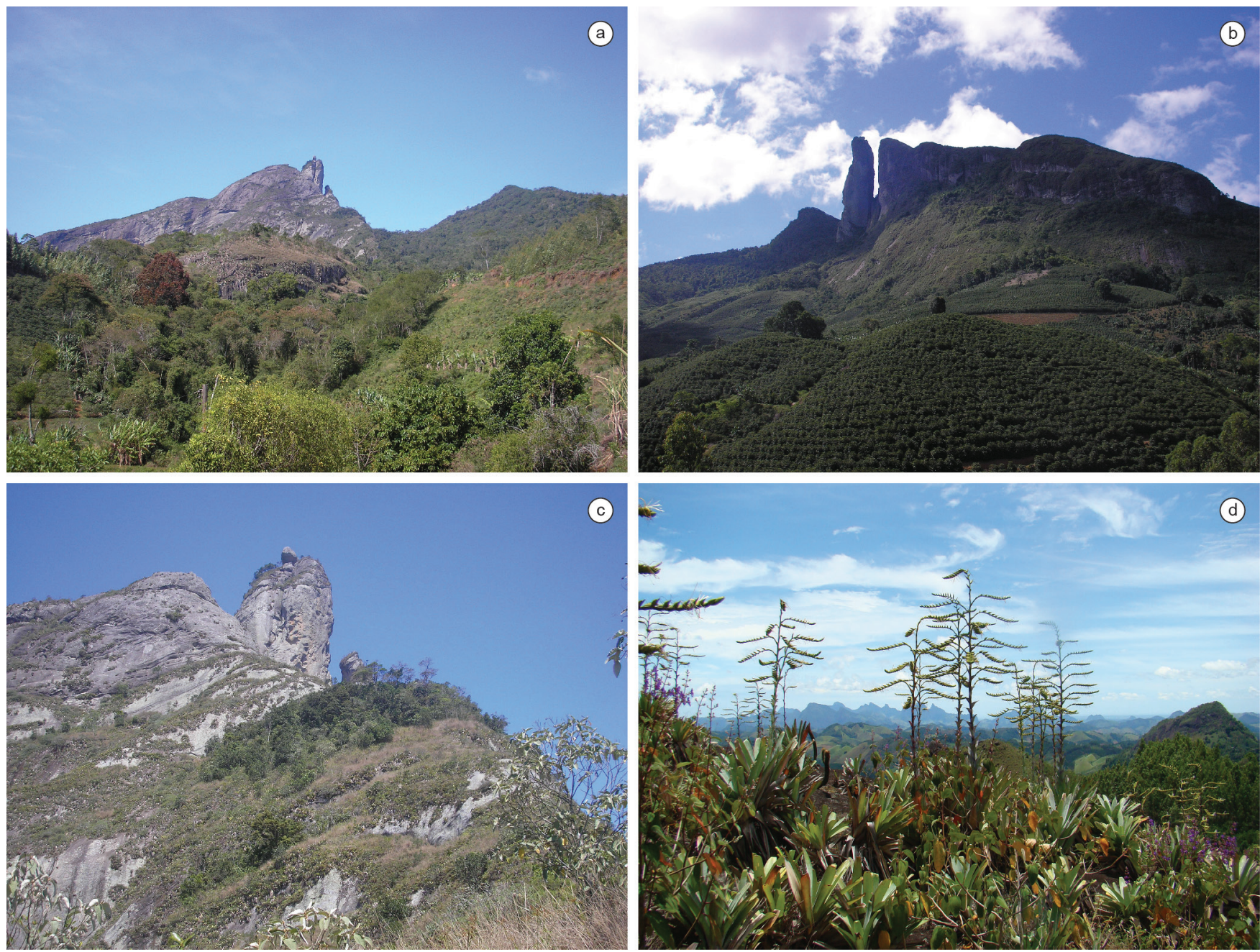

Figure 2. Some types of vegetation found in the study area. Montane dense ombrophile forest (a) and areas of coffee plantations (b) with Pedra dos Pontões behind. Patches of rocky vegetation (c) and detail of the rocky vegetation (d). 
Table 1. Bromeliaceae checklist from Pedra dos Pontões, Mimoso do Sul, ES, Brazil. Species are organized by subfamilies (sensu Smith \& Downs 1979) and followed by the collector number and voucher. Ecological information, such as (1) distribution in different habitats; (2) types of habit and (3) local abundance estimations are listed as follow: (1) $\mathrm{Mf}=$ montane forest; $\mathrm{Rv}=$ rocky vegetation. (2) $\mathrm{Ep}=$ epiphyte; $\mathrm{Ter}=$ terricolous; $\mathrm{Ru}=$ rupicolous. $(3) \mathrm{Co}=$ common, $\mathrm{Oc}=$ occasional, $\mathrm{Re}=$ retrict; $\mathrm{Ra}=$ rare. ${ }^{*}=$ Endemic to the Espírito Santo state, ${ }^{* *}=$ Endemic to the studied area, ${ }^{*}=$ First register of occurrence for Espírito Santo state.

\begin{tabular}{cc}
\hline SUBFAMILY & Ecological information and geographic \\
\hline Taxon and voucher & coordinates \\
\hline
\end{tabular}

\section{BROMELIOIDEAE}

Aechmea coelestis (K. Koch) E. Morren

D. R. Couto 1.290 (MBML)

Aechmea lamarchei Mez

D. R. Couto 928 (MBML)

Aechmea nudicaulis (L.) Griseb.

V. C. Manhães 18 (MBML)

Aechmea ramosa Mart. ex Schult. \& Schult.f.

D. R. Couto 180 (MBML)

Aechmea saxicola L.B.Sm.

V. C. Manhães 27 (MBML)

Aechmea squarrosa Baker

D. R. Couto 179 (MBML)

Billbergia horrida Regel

V. C. Manhães 15 (MBML)

Billbergia iridifolia (Nees \& Mart.) Lindl.

D. R. Couto 175 (MBML)

Billbergia lietzei E.Morren*

D. R. Couto 1.450 (MBML)

Billbergia porteana Brong. ex Beer

V. C. Manhães 6 (MBML)

Billbergia tweedieana Baker

D. R. Couto 2.069 (VIES)

Billbergia vittata Brong.

D. R. Couto 1.030 (MBML)

Billbergia zebrina (Herb.) Lindl

D. R. Couto 2.111 (VIES)

Bromelia antiacantha Bertol.

V. C. Manhães 42 (MBML)

Edmundoa lindenii (Regel) Leme

V. C. Manhães 25 (MBML)

Neoregelia dayvidiana Leme \& A.P.Fontana**

E. Leme 7.566 (MBML)

Neoregelia pauciflora L.B.Sm*

V. C. Manhães 41 (MBML)

Nidularium antoineanum Wawra ${ }^{\#}$

D. R. Couto 2.019 (VIES)

Nidularium procerum Lindm.

V. C. Manhães 29 (MBML)

Quesnelia aff. arvensis (Vell.) Mez

D. R. Couto 2.068 (VIES)

Quesnelia kautskyi C.M.Vieira

L. Kollmann 6.802 (MBML)

Quesnelia strobilispica Wawra

V. C. Manhães 26 (MBML)

PITCAIRNIOIDEAE

Pitcairnia abyssicola Leme \& L.Kollmann**

E. Leme 7.573 (MBML)

Pitcairnia decidua L.B.Sm.

V. C. Manhães 9 (MBML)

Pitcairnia flammea Lindl.
Mf; 1.290 m; Ep. Ra

$20^{\circ} 56^{\prime} 16^{\prime \prime} \mathrm{S} ; 41^{\circ} 33^{\prime} 21^{\prime \prime} \mathrm{W}$

Mf; 700-1.220 m; Te. Re

$20^{\circ} 55^{\prime} 57^{\prime \prime} \mathrm{S} ; 41^{\circ} 33^{\prime} 2,7^{\prime \prime} \mathrm{W}$

Rv/Mf; 700-950 m; Ep. Co

$20^{\circ} 56^{\prime} 31^{\prime \prime} \mathrm{S} ; 41^{\circ} 32^{\prime} 45^{\prime \prime} \mathrm{W}$

Rv/Mf; 700-900 m; Ep. Co

2056’20,1” S; 41॰32’37” W

Rv; 700 m; Ep/Te. Re

2056'19,9” S; 41³2'39” W

Rv/Mf; 710-1.000 m; Ep/Ru. Oc

$20^{\circ} 56^{\prime} \mathrm{S} ; 41^{\circ} 32^{\prime} \mathrm{W}$

Rv/Mf; 730-900 m; Ep. Co

$20^{\circ} 56^{\prime} 18,5$ ' S; 41 32 ' $36^{\prime \prime} \mathrm{W}$

Rv; 730 m; Ter. Re

$20^{\circ} 56^{\prime} 20,7$, S; 41 $31^{\circ}$ ' 38,3” W

Rv; 710 m; Ru. Ra

$20^{\circ} 56^{\prime} 21,3$ ' S; 41 32' 38,7” W

Rv; 723 m; Ep. Re

$20^{\circ} 56^{\prime} 20,8^{\prime \prime} \mathrm{S} ; 41^{\circ} 32$ ' 34,8” W

Rv; 740 m; Ep/Ter. Re

$20^{\circ} 56^{\prime} 17,7^{\prime \prime} \mathrm{S} ; 41^{\circ} 32$ ' 37,9” W

Mf; 710 m; Ep. Re

$20^{\circ} 56^{\prime} 8,9$ ' S; 41 43 ' 1 ' W

Rv/Mf; 720 m; Ep. Oc

$20^{\circ} 56^{\prime} 17,8^{\prime \prime} \mathrm{S}$; 41 $31^{\circ} 32^{\prime} 37,5^{\prime \prime} \mathrm{W}$

Rv/Mf; 700-1.100 m; Te. Co

$20^{\circ} 56^{\prime} 22,2$ " S; 41 32 32' 31,6” W

Rv/Mf; 700-1.110 m; Ep/Ter. Co

$20^{\circ} 55^{\prime} 58,9$ ” S; 41 33' 3,6” W

Rv; 710-1.045 m; Ep. Re

$20^{\circ} 56^{\prime} \mathrm{S} ; 41^{\circ} 33^{\prime} \mathrm{W}$

Rv; 733 m; Ep. Re

$20^{\circ} 56^{\prime} 19,1^{\prime \prime} \mathrm{S} ; 41^{\circ} 32$ ' 33,9” W

Mf; 1.080 m; Ep. Re

$20^{\circ} 56^{\prime} 20^{\prime \prime} \mathrm{S} ; 41^{\circ} 33$ ' 24,8” W

Rv; 700 m; Ter. Re

$20^{\circ} 56^{\prime} 21,8^{\prime \prime} \mathrm{S} ; 41^{\circ} 32$ ' 35,6” W

Rv/Mf; 730 m; Te. Oc

$20^{\circ} 56^{\prime} 21,2$ " $\mathrm{S}$; $41^{\circ} 32$ ' $32,8^{\prime \prime} \mathrm{W}$

Rv; 700-1.050 m; Te. Re

$20^{\circ} 56^{\prime} 19$ ' S; 41 32' 37' W

Rv; $710 \mathrm{~m}$; Te. Re

$20^{\circ} 56^{\prime} 18^{\prime \prime} \mathrm{S} ; 41^{\circ} 32$ ' 37' W W

Rv; 1.000-1.290 m; Ru. Ra

$20^{\circ} 56^{\prime} \mathrm{S} ; 41^{\circ} 33^{\prime} \mathrm{W}$

Rv; 700-910 m; Ru. Re

$20^{\circ} 56$ ' 31,7” S; 41 32 ' 43” W

Rv; 930 m; Ru. Re 
Table 1. Continued...

\begin{tabular}{|c|c|}
\hline SUBFAMILY & Ecological information and geographic \\
\hline Taxon and voucher & coordinates \\
\hline D. R. Couto 1.102 (MBML) & $20^{\circ} 56^{\prime} 21,7^{\prime \prime} \mathrm{S} ; 41^{\circ} 32^{\prime} 54,1^{\prime \prime} \mathrm{W}$ \\
\hline Pitcairnia glaziovi Baker & $\mathrm{Rv} ; 1.310 \mathrm{~m}$; Ru. Ra \\
\hline D. R. Couto 941(VIES) & $20^{\circ} 56^{\prime} 19,1^{\prime \prime} \mathrm{S} ; 41^{\circ} 33^{\prime} 20,8^{\prime \prime} \mathrm{W}$ \\
\hline \multicolumn{2}{|l|}{ TILLANDSIOIDEAE } \\
\hline Alcantarea patriae Versieux \& Wand.* & $\mathrm{Rv} ; 700-1.350 \mathrm{~m} ; \mathrm{Ru} . \mathrm{Re}$ \\
\hline V. C. Manhães 7 (MBML) & $20^{\circ} 56^{\prime} 24^{\prime \prime} \mathrm{S} ; 41^{\circ} 32^{\prime} 48^{\prime \prime} \mathrm{W}$ \\
\hline Catopsis sessiliflora (Ruiz \& Pav.) Mez & Rv; 710 m; Ep. Re \\
\hline D. R. Couto 1.350 (MBML) & $20^{\circ} 56^{\prime} 20,1^{\prime \prime} \mathrm{S} ; 41^{\circ} 32^{\prime} 38,7^{\prime}$ W \\
\hline Tillandsia gardneri Lindl. & Rv/Mf; 720-1.040; Ep. Co \\
\hline V. C. Manhães 36 (MBML) & $20^{\circ} 56^{\prime} 1^{\prime \prime} \mathrm{S} ; 41^{\circ} 32^{\prime} 59,2^{\prime \prime} \mathrm{W}$ \\
\hline Tillandsia geminiflora Brongn. & Rv/Mf; 710-1.290 m; Ep. Co \\
\hline D. R. Couto 912 (MBML) & $20^{\circ} 56^{\prime} 3,8^{\prime \prime} \mathrm{S} ; 4^{\circ} 33^{\prime} 8,4^{\prime \prime} \mathrm{W}$ \\
\hline Tillandsia recurvata (L.) L. & Rv; 712 m; Ep. Re \\
\hline L. Kollmann 6.829 (MBML) & $20^{\circ} 56^{\prime} 20^{\prime \prime} \mathrm{S} ; 41^{\circ} 32^{\prime} 39,6^{\prime \prime} \mathrm{W}$ \\
\hline Tillandsia stricta Sol. & Rv/Mf; 730 m; Ep. Oc \\
\hline D. R. Couto 296 (MBML) & $20^{\circ} 56^{\prime} 29,8^{\prime \prime} \mathrm{S} ; 41^{\circ} 32^{\prime} 41,6^{\prime \prime} \mathrm{W}$ \\
\hline Tillandsia tenuifolia $\mathbf{L}$. & Rv/Mf; 710-800 m; Ep. Oc \\
\hline L. Kollmann 6.794 (MBML) & $20^{\circ} 56^{\prime} 18,7^{\prime \prime} \mathrm{S} ; 41^{\circ} 32^{\prime} 36,8^{\prime \prime} \mathrm{W}$ \\
\hline Tillandsia usneoides (L.) L. & Rv/Mf; 710-800 m; Ep. Oc \\
\hline D. R. Couto 252 (MBML) & $20^{\circ} 56^{\prime} 19^{\prime \prime} \mathrm{S} ; 41^{\circ} 32 ’ 39,1{ }^{\prime \prime} \mathrm{W}$ \\
\hline Vriesea sp. & Mf; 1.210 m; Ep. Re \\
\hline D. R. Couto 1.975 (VIES) & $20^{\circ} 56^{\prime} 10,5^{\prime \prime} \mathrm{S} ; 41^{\circ} 33^{\prime} 21,7^{\prime} \mathrm{W}$ \\
\hline Vriesea carinata Wawra & Mf; 1.290 m; Ep. Re \\
\hline D. R. Couto 901 (MBML) & $20^{\circ} 56^{\prime} 4,3^{\prime \prime} \mathrm{S} ; 41^{\circ} 33^{\prime} 8,8^{\prime \prime} \mathrm{W}$ \\
\hline Vriesea ensiformis (Vell.) Beer & Mf; 1.250 m; Ep. Re \\
\hline V. C. Manhães 33 (MBML) & $20^{\circ} 56^{\prime} 19,99^{\prime} \mathrm{S} ; 41^{\circ} 32^{\prime} 39^{\prime \prime} \mathrm{W}$ \\
\hline Vriesea fosteriana L.B.Sm. & Rv; 700-1.290 m; Ru. Re \\
\hline V. C. Manhães 30 (MBML) & $20^{\circ} 56^{\prime} 20,3^{\prime \prime} \mathrm{S} ; 41^{\circ} 33^{\prime} 21,5^{\prime \prime} \mathrm{W}$ \\
\hline Vriesea gigantea Gaudich. & Rv; 710 m; Ep. Re \\
\hline D. R. Couto 2.111 (VIES) & $20^{\circ} 56^{\prime} 19,5 ” \mathrm{~S} ; 41^{\circ} 32^{\prime} 39^{\prime \prime} \mathrm{W}$ \\
\hline Vriesea lubbersii (Baker) E. Morren & Rv; 730-800 m; Ep. Co \\
\hline V. C. Manhães 5 (MBML) & $20^{\circ} 56^{\prime} 18,9^{\prime \prime} \mathrm{S} ; 41^{\circ} 32^{\prime} 34,1^{\prime \prime} \mathrm{W}$ \\
\hline Vriesea pardalina $\mathbf{M e z}^{\#}$ & Mf; 1200 m; Ep. Re \\
\hline V. C. Manhães 35 (MBML) & $20^{\circ} 56^{\prime} 17,8^{\prime \prime} \mathrm{S} ; 41^{\circ} 33^{\prime} 23,1^{\prime \prime} \mathrm{W}$ \\
\hline Vriesea pseudoatra Leme ${ }^{\#}$ & $\mathrm{Rv} ; 1.220 \mathrm{~m} ; \mathrm{Ru} . \mathrm{Re}$ \\
\hline D. R. Couto 940 (MBML) & $20^{\circ} 56^{\prime} 22,9^{\prime \prime} \mathrm{S} ; 41^{\circ} 33^{\prime} 20,1^{\prime \prime} \mathrm{W}$ \\
\hline Vriesea racinae L.B.Sm. & Mf; 800 m; Ep. Re \\
\hline D. R. Couto 1.135 (MBML) & $20^{\circ} 56^{\prime} 10,2^{\prime \prime} \mathrm{S} ; 41^{\circ} 33^{\prime} 3,0^{\prime \prime} \mathrm{W}$ \\
\hline Vriesea scalaris E. Morren & Mf; 1.100 m; Ep. Re \\
\hline V. C. Manhães 34 (MBML) & $20^{\circ} 56^{\prime} 3,8^{\prime \prime} \mathrm{S} ; 41^{\circ} 33^{\prime} 20,4^{\prime \prime} \mathrm{W}$ \\
\hline
\end{tabular}

13 species were observed in both types of vegetation. In relation to the local abundance, $59 \%$ of the taxa ( 26 species) were categorized as restrict, $18 \%$ (eight species) as common, $13.6 \%$ (six species) as occasional and 9\% (four species) as rare (Table 1 and Figure 3).

The altitudinal range where species richness was higher lies between 700 and 1.310 m.a.s.l. (Figure 4). Above the $1.300 \mathrm{~m}$ of elevation, we registered an in increase on the richness of Tillandsioideae species (genera Alcantarea, Tillandsia and Vriesea). Only Billbergia has showed preferential distribution for elevation between 700 and $750 \mathrm{~m}$, with the exception of $B$. horrida Regel, that grows between 700 and $900 \mathrm{~m}$.

The first occurrence for the Espírito Santo state is reported here for Aechmea. squarrosa Baker, Nidularium antoineanum Wawra, Vriesea pseudoatra Leme and Vriesea pardalina Mez. The species $A$. squarrosa (Figure 5a) and V. pseudoatra (Figure 5d) were previously restricted to Rio de Janeiro state. $N$. antoineanum (Figure $5 \mathrm{~b}$ ) and $V$. pardalina (Figure $5 \mathrm{c}$ ), otherwise, have been registered for São Paulo, Rio de Janeiro and Minas Gerais states, and now have their distribution extended to the whole Brazilian southeast region. This work also registers species with endemic distribution for the Espírito Santo: Alcantarea patriae Versieux \& Wand, Vriesea fosteriana L.B.Sm., Billbergia lietzei E.Morren, Neoregelia dayvidiana Leme \& A.P.Fontana and Pitcairnia abyssicola Leme \& L.Kollmann. The last two taxa were originally described from the Pedra dos Pontões, and so far are still known only for the type locality.

Four species surveyed are reported in the official list of endangered species of Espírito Santo (Espírito Santo 2005) as "Vulnerable": Billbergia lietzei (Figure 5e), Quesnelia. kautskyi 


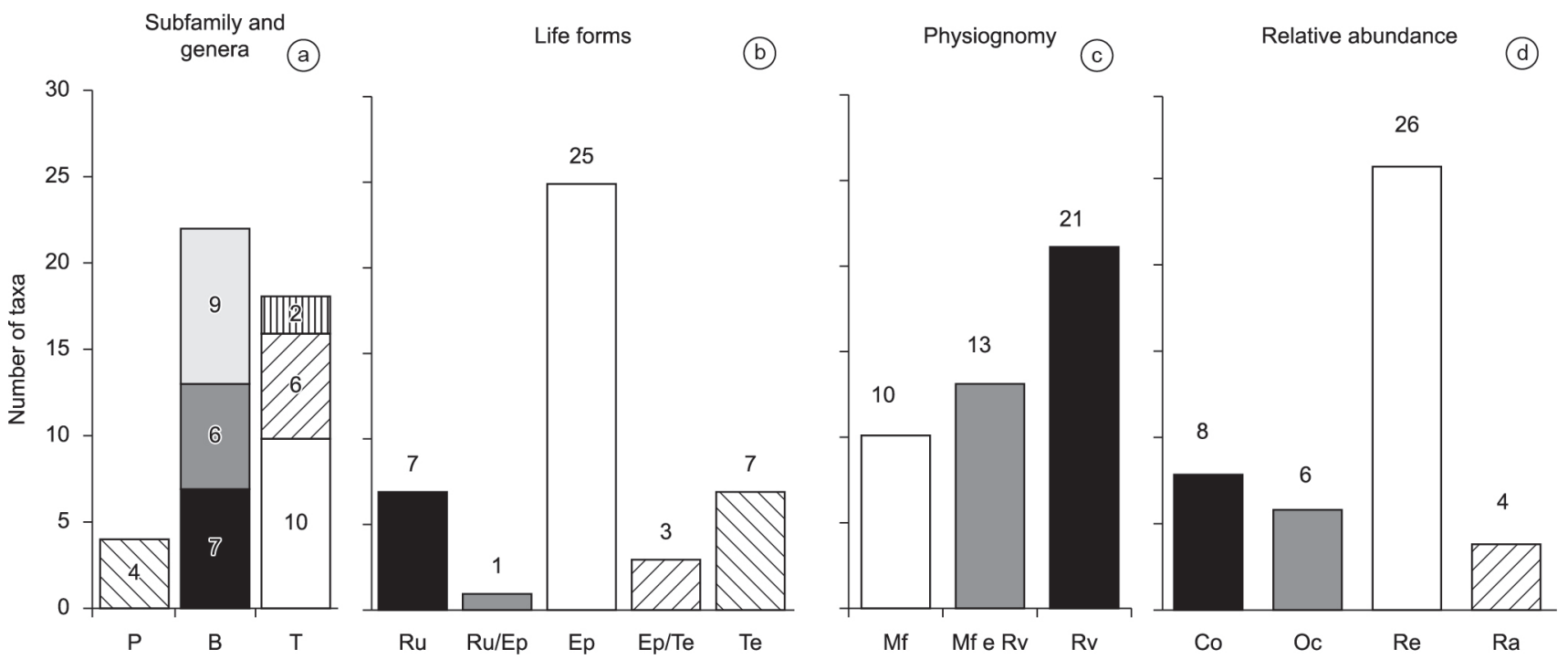

Figure 3. Distribution of the Bromeliaceae species. A. Subfamilies Pitcairnoideae (P), Bromelioideae (B) and Tillandsioideae (T) and in the principal genera (black bars $=$ Billbergia, dark gray $=$ Aechme, light gray $=$ other genera of Bromelioideae, white $=$ Vriese, , hatched $=$ Tillandsia, stippled $=$ other Tillandsioideae . B. Life forms (black= rupicolous, gray= rupicolous and epiphyte, white $=$ epiphyte, hatched $=$ epiphyte and terricolous, stippled $=$ terricolous). C. Physiognomy (white $=$ montane forest, gray $=$ montane forest and rocky outcrop vegetation, black $=$ rocky outcrop vegetation) $\mathbf{D}$. Classes of relative abundance $($ black $=$ common, gray $=$ occasional, white $=$ retricted; hatched $=$ rare).

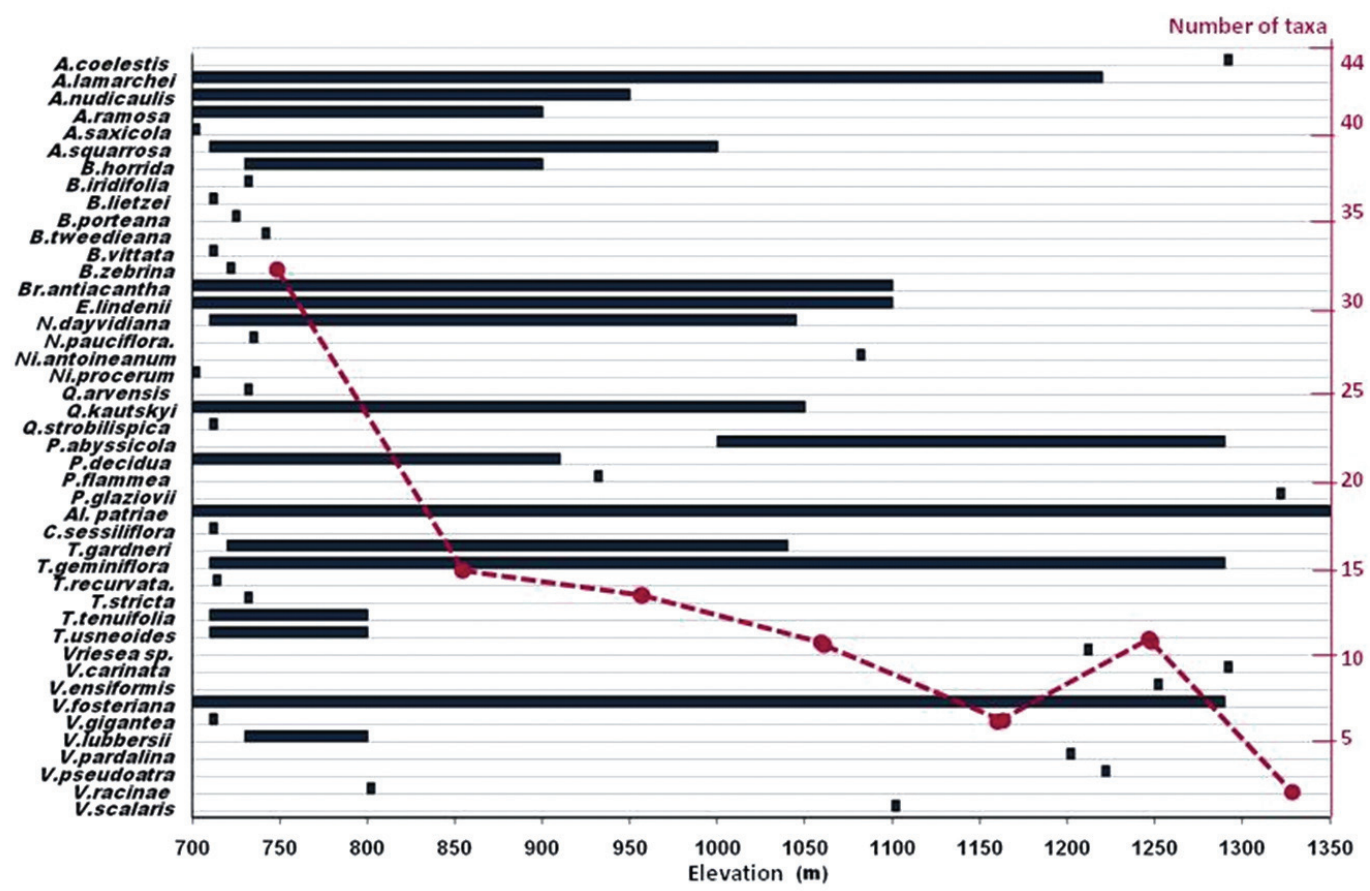

Figure 4. Distribution of the Bromeliaceae species surveyed for the Pedra dos Pontões, according to their occurrence in different altitudinal ranges (the red line indicates the total number of species in each altitudinal range).

C.M.Vieira (Figure 5f), Pitcairnia decidua L.B.Sm. and Vriesea racinae L.B.Sm. (Figure 5g) and one as "Endangered" (V.fosteriana). None of the species studied is cited in the list of endangered Brazilian flora species (Brasil 2008). However, $V$. fosteriana and $V$. racinae are reported as "Data Deficient" and further studies about the geographic distribution and potential threats are necessary to a better definition of the conservation status of these species.

\section{Discussion}

In terms of species richness and diversity, despite its importance for the flora of Espírito Santo, taxonomic inventories concerning Bromeliaceae are still scarce in the state, and most published works have been related to descriptions of new taxa. At the central portion of the state, in areas of dense ombrophile forest of the municipality of 

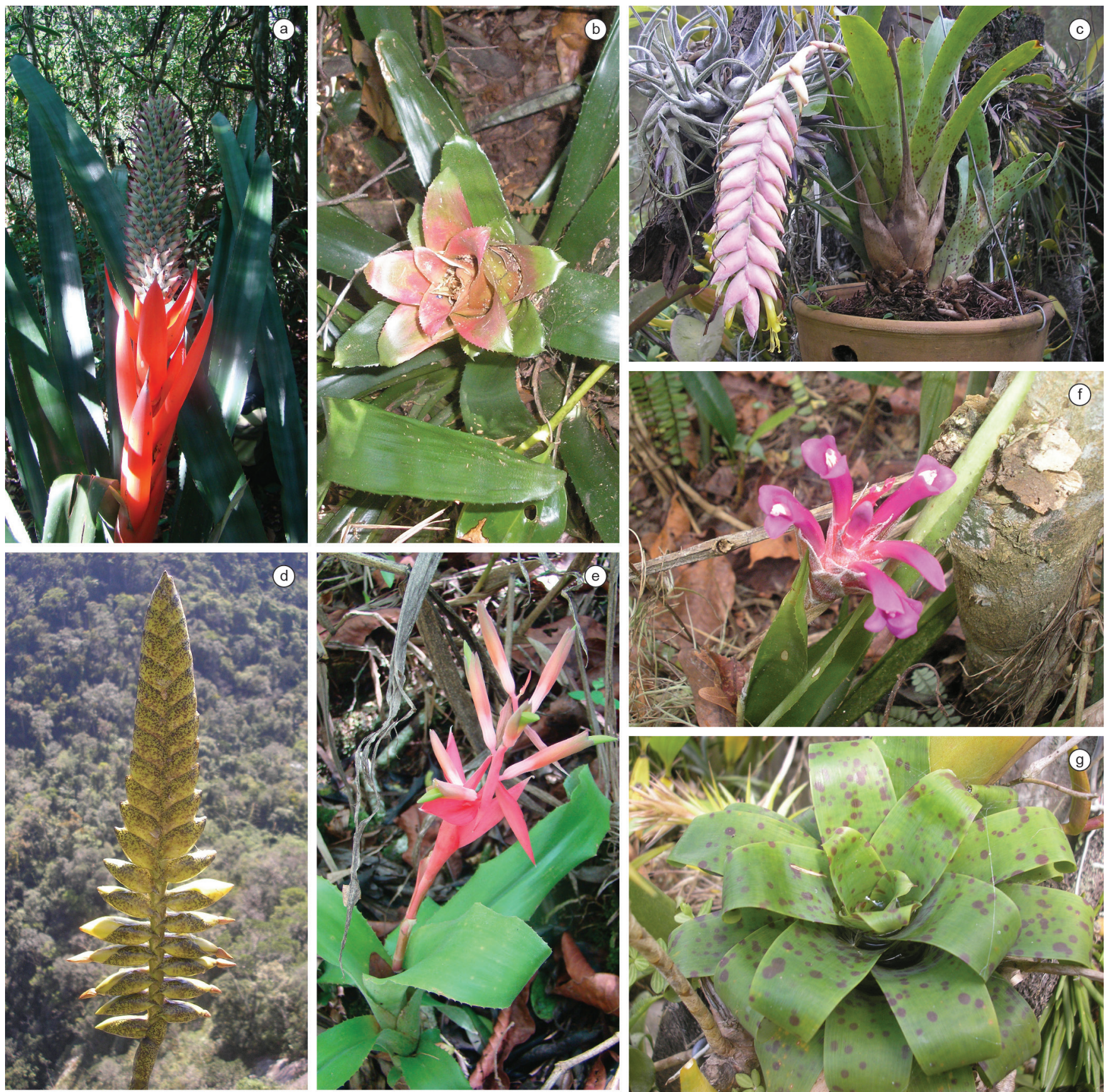

Figure 5. Some species of Bromeliaceae found in the Pedra dos Pontões. First records for the Espírito Santo state (a-d); Aechmea squarrosa Baker (a); Nidularium antoineanum Wawra (b); Vriesea pardalina Mez (c); Vriesea pseudoatra Leme (d). Some endangered species registered for the state (e-g); Billbergia lietzei E.Morren (e); Quesnelia kautskyi C.M.Vieira (f); Vriesea racinae L.B.Sm. (g).

Santa Teresa, Wendt et al. (2010) surveyed 107 taxa of Bromeliaceae (about a third of the total known for the Espírito Santo). Esgario et al. (2009) listed 11 species of Bromeliaceae in an inventory of the vascular flora associated to rocky vegetation in the region of Alto Misterioso. Silva \& Gomes $(2003,2005)$ studied the bromeliads in municipality of Serra, and registered 19 and 23 species, respectively. For the southern portion of the state, Assis et al. (2004) surveyed 14 species in areas of sandy coastal plains (restinga) in the municipality of Guarapari.

Compared to the studies mentioned above, the Pedra dos Pontões presents a relevant species richness of Bromeliaceae, what strengthens the importance of the phytophysiognomies associated to rocky outcrops in the maintenance of the diversity and endemism for many taxa of the family. Some species registered in the area (e.g. Aechmea squarrosa, Billbergia lietzei, Neoregelia dayvidiana, Pitcairnia abyssicola, P. glaziovii Baker and Vriesea racinae) are of great conservation importance, due to their restrict geographic distribution, few collections in the field and consequently scarce records in herbarium.

This work highlight that the documentation and study of the flora of Espírito Santo assumes a more relevant aspect in view of the high levels of degradation of the natural ecosystems observed in 
the state. The south portion of the Espírito Santo figurate as one of the most deprived of protected areas. The mountain regions of Alto Calçado and Serra das Torres, for example, are indicated as having great priority for implantation of Conservation Units (Instituto... 2012). Our results suggest that this conservation strategy should be extended for the neighboring fragments of Mimoso do Sul, including the studied area, also through the implantation of protected areas or connecting them through ecological corridors.

\section{Acknowledgements}

We thank to Antônio Mazza (in memoriam) and his family, Roberto Bellato and Cristiane Massini, for issuing the necessary permits to plant collection within their particular propriety; Ludovic Kollmann, Andre Fontana, Elton Leme and Thiago Coser, for helping during the fieldworks and taxonomic identifications; Helio Fernandes (curator of MBML herbarium) and Henrique Machado Dias (herbarium VIES, subcuratory Alegre/Jerônimo Monteiro), for logistic support.

\section{References}

ASSIS, A.M., THOMAZ, L.D. \& PEREIRA, O.J. 2004. Florística de um trecho de floresta de restinga no município de Guarapari, Espírito Santo, Brasil. Acta bot. bras. 18(1):191-201.

ASSIS, A.M., MAGNAGO, L.F.S. \& FERNADES, H.Q.B. 2007. Floresta Estacional Semidecidual de Terras Baixas, Submontana e Montana. In Espécies da flora ameaçadas de extinção no estado Espírito Santo (C.N. Fraga \& M. Simonelli, eds). IPEMA, Vitória, p.51-54.

BRASIL. Ministério do Meio Ambiente. Anexo I da Instrução Normativa $\mathrm{n}^{\circ}$ 6, de 23 de setembro de 2008. Lista Oficial das Espécies da Flora Brasileira Ameaçadas de Extinção. Diário Oficial da República Federativa do Brasil, Brasília, DF, 09 out. 2008. http://www.mma.gov.br/estruturas/ ascom_boletins/_arquivos/83_19092008034949.pdf (último acesso em 15/08/2012).

COMPANHIA DE PESQUISA DE RECURSOS MINERAIS - CPRM. 1995. Programas de levantamentos geológicos básicos do Brasil. 1:250.000. Folha SF.24-V-A. Cachoeiro de Itapemirim. Belo Horizonte.

ESGARIO, C.P., FONTANA, A.P. \& SILVA, A.G. 2009. A flora vascular sobre rocha no Alto Misterioso, uma área prioritária para a conservação da Mata Atlântica no Espírito Santo, Sudeste do Brasil. Natureza On Line 7(2):8091 http://www.naturezaonline.com.br (último acesso em 15/08/2012)

ESPÍRITO SANTO. Decreto n ${ }^{\circ}$ 1499-R, de 13 de junho de 2005. Declara as espécies da fauna e flora silvestres ameaçadas de extinção no Estado do Espírito Santo, e dá outras providências. Diário Oficial do Estado do Espírito Santo, 16 jun. 2005.

FORZZA, R.C., COSTA, A., SIQUEIRA FILHO, J.A. \& MARTINELLI, G. 2010. Bromeliaceae. In: Lista de Espécies da Flora do Brasil. Jardim Botânico do Rio de Janeiro. http://floradobrasil.jbrj.gov.br/2010/ FB000066 (último acesso em 15/08/2012)

FRAGA, C.N., SIMONELLI, M. \& FERNANDES, H.Q.B. 2007. Metodologia utilizada na elaboração da lista da flora ameaçada de extinção no Espírito Santo. In Espécies da flora ameaçadas de extinção no estado Espírito Santo (C.N. Fraga \& M. Simonelli, eds.). IPEMA, Vitória, p.59-72.

GOVAERTS, R., LUTHER, H.E. \& GRANT, J. 2012. World Checklist of Bromeliaceae. Facilitated by the Royal Botanic Gardens, Kew. http:// apps.kew.org/wcsp/ (ultimo acesso em 10/09/2012).
INSTITUTO ESTADUAL DE MEIO AMBIENTE - IEMA. Áreas prioritárias para conservação no Espírito Santo. http://www.meioambiente.es.gov.br/ download/Anexo_Areas_PRIORITARIAS_para_CONSERVACAO.pdf. (último acesso em 10/09/2012).

KÖPPEN, W. 1948. Climatologia: con un estudio de los climas de la tierra. Fondo de Cultura Econômica, México.

LEME, E.M.C., KOLLMANN, L.J.C. \& FONTANA, A.P. 2009. Two new species from Pedra dos Pontões, an unexplored mountain in Espírito Santo, Brazil. J. Bromeliad Soc. 59(4):145-192.

LEME, E.M.C., FRAGA, C.N., KOLLMANN, L.J.C., BROWN, G.K., TILL, W., RIBEIRO, O.B.C., MACHADO M.C., MONTEIRO, F.J.S. \& FONTANA, A.P. 2010a. Miscellaneous new species in the Brazil Bromeliaceae. Rodriguésia 61(1):021-067.

LEME, E.M.C., FONTANA, A.P. \& HALBRITTER, H. 2010b. Three New Pitcairnia Species (Bromeliaceae) from the Inselbergs of Espírito Santo, Brazil. Syst. Bot. 35(3):487-496. http://dx.doi. org/10.1600/036364410792495971

MARTINELLI, G. 2007. Mountain biodiversity in Brazil. Rev. Bras. Bot. 30(4):587-597. http://dx.doi.org/10.1590/S010084042007000400005

MARTINELli, G. \& FORZZA, R.C. 2006. Pitcairnia L.Hér. (Bromeliaceae):uma nova espécie, P. azouryi Martinelli \& Forzza, e observações sobre P. encholirioides L. B. Sm. Rev. Bras. Bot. 29(4):603607. http://dx.doi.org/10.1590/S0100-84042006000400010

MARTINELLI, G.,VIEIRA, C.M., GONZALEZ, M., LEITMAN, P., PIRATININGA, A., COSTA, A.F. \& FORZZA, R.C. 2008. Bromeliaceae da Mata Atlântica brasileira: lista de espécies, distribuição e conservação. Rodriguésia 59(1):209-258.

MYERS, N., MITTERMEIER, R.A., MITTERMEIER, C.G., FONSECA, G.A.B. \& KENT, J. 2000. Biodiversity hotspots for conservation priorities. Nature 403:853-858. http://dx.doi.org/10.1038/35002501

RIZZINI, C.T. 1997. Tratado de Fitogeografia do Brasil, aspectos ecológicos, sociológicos e florísticos. 2. ed. Editora Âmbito Cultural, Rio de Janeiro.

SILVA, N.N.F. \& GOMES J.M.L. 2003. Bromeliaceae do Sítio Morro do Céu, Serra (ES). Natureza On Line 1(2):1-11. http://www.naturezaonline.com. br (último acesso em 15/08/2012).

SILVA, N.N.F. \& GOMES, J.M.L. 2005. Bromeliaceae do Sítio Santo Antônio, Morro do Céu, Itaiobaia, Serra-ES. Enciclopédia Biosfera 01:1-29.

SIMONELLI, M., FRAGA, C.N. \& FERNANDES, H.Q.B. 2007. Situação atual da flora ameaçada no Estado do Espírito Santo. In Espécies da flora ameaçadas de extinção no estado Espírito Santo (C.N. Fraga \& M. Simonelli eds). IPEMA, Vitória, p.73-80.

SMITH, L. B. \& DOWNS, R .J. 1979. Bromelioideae (Bromeliaceae). Flora Neotropica Monograph 14(3): 1493-2141. New York Botanical Garden

VELOSO, H.P., RANGEL FILHO, A.L.R. \& LIMA, J.C.A. 1991. Classificação da vegetação brasileira, adaptada a um sistema universal. IBGE, Rio de Janeiro.

VERSIEUX, L. \& WANDERLEY, M.G.L. 2007. Anew species of Alcantarea (E. Morren ex Mez) Harms, Bromeliaceae. Hoehnea 34(3):409-413. http:// dx.doi.org/10.1590/S2236-89062007000300009

VERSIEUX, L.M., LOUZADA, R.B., VIANA, P.L., MOTA, N. \& WANDERLEY, M.G.L. 2010. An illustrated checklist of Bromeliaceae from Parque Estadual do Rio Preto, Minas Gerais, Brazil, with notes on phytogeography and one new species of Cryptanthus. Phytotaxa 10:1-16.

WENDT, T., COSER, T.S., BOUDET-FERNANDES, H. \& MARTINELLI, G. 2010. Bromeliaceae do município de Santa Teresa, Espírito Santo: lista de espécies, distribuição, conservação e comentários taxonômicos. Bol. Mus. Biol. Mello Leitão 27:21-53. 